\title{
Вивчення впливу колагену на перебіг місцевих тканинних реакцій та післяопераційного періоду при імплантаціі поліпропіленового протеза
}

\author{
Б. С. Запорожченко ${ }^{1}$, І. Г. Холодов ${ }^{1,2}$, В. В. Колодій ${ }^{1}$, А. А. Горбунов ${ }^{1}$, Д. А. Бондарець ${ }^{1}$
}

${ }^{1}$ Одеський національний медичний університет,

${ }^{2}$ Військово-медичний клінічний центр ДПС України, м. Одеса

\section{Studying of impact of collagen on course of a local tissue reactions and postoperative period while implantation of polypropilene prosthesis}

\author{
B. S. Zaporozhchenko ${ }^{1}$, I. G. Kholodov ${ }^{2}$, V. V. Kolodiy ${ }^{1}$, A. A. Gorbunov ${ }^{1}$, D. A. Bondarets ${ }^{1}$ \\ ${ }^{1}$ Odessa National Medical University, \\ ${ }^{2}$ Military-Medical Clinical Centre of the SBF of Ukraine, Odesa
}

\begin{abstract}
Реферат
Вступ. Висока частота гриж живота зумовлює актуальність питання вдосконалення результатів їх хірургічного лікування.

Матеріали і методи. Експериментально вивчено вплив перорального застосування препарату колагену на формування сполучнотканинних структур у зоні розташування поліпропіленового імплантата у дорослих самців щурів лінії Wistar. Проаналізовано перебіг післяопераційного періоду і результати лікування 57 хворих, яким застосовували препарат колаген після алогерніопластики з приводу гриж живота.

Результати. Встановлено, що у щурів, яким давали препарат колаген, поля фіброзу були менші, новоутворені волокна колагену мали впорядковану структуру, більшу щільність. Еластичні волокна спостерігали у більшій кількості не лише по периферії сполучної тканини, а й у центральних ділянках. За допомогою ультразвукового дослідження (УзД) встановлено збільшення товщини сполучнотканинного компонента у зоні поліпропіленового протеза в післяопераційному періоді у разі вживання колагену.

Висновок. Застосування колагену стимулює неоангіогенез, оптимізує утворення достатньої кількості зрілої сполучної тканини у периімплантаційній зоні, позитивно впливає на товщину сполучнотканинного компонента у зоні розташування поліпропіленового протеза в ранньому післяопераційному періоді.

ключові слова: грижі; колаген; стимуляція колагеногенезу; алотрансплантація.

Abstract

Introduction. High occurrence of abdominal hernias makes actual the issue of improving their surgical treatment results. Materials and methods. Impact of peroral administration of a collagen preparation on formation of the connective tissue structure in the zone of polypropylene implant placement in adult male rats of a Wistar line was studied. The postoperative period course and results of treatment of 57 patients, in whom collagen preparation have been applied after allohernioplasty for abdominal hernias, were analyzed.

Results. There was established, that in rats, after collagen administering, the fibrosis fields were lesser and a newly created fibers of collagen have had organized structure and enhanced density. Elastic fibers were observed in enhanced quantity not only in the connective tissue periphery, but in central parts as well. Using ultrasound investigation there was established, that while use of collagen, the connective tissue component thickness in zone of placement of polypropilene prosthesis in postoperative period is enhanced.

Conclusion. Collagen application stimulates neoangiogenesis, optimizes creation of enough quantity of mature connective tissue in periimplantation zone, impacts positively the connective tissue component thickness in zone of placement of polypropilene prosthesis in early postoperative period.

Keywords: hernias; collagen; stimulation of collagenogenesis; allotransplantation.
\end{abstract}

Однією з найбільших проблем у хірургічному лікуванні гриж живота є їх рецидиви та ускладнене приживлення імплантатів. Не вирішене питання мінімізації реакції організму на імплантацію поліпропілену. Тому пошук шляхів покращення приживлення поліпропіленового протеза триває [1].

Хоча в ряді робіт повідомляеться про патологію, у тому числі генетично детерміновану, сполучної тканини та порушення синтезу колагену як предикторів розвитку рецидиву грижі, процес інтеграції імплантатів у сполучну тканину вивчений не повністю [2]. В цьому сенсі пероральне використання препарату колагену викликае неабиякий інтерес з позиції вивчення впливу тваринного колагену на формування повноцінної сполучної тканини $[3,4]$.

Мета дослідження: вивчити вплив препарату колагену на формування сполучнотканинних структур у зоні розташування поліпропіленового імплантата в експерименті, дослідити перебіг післяопераційного періоду та поліпшити результати лікування хворих через застосування препарату колагену після алогерніопластики 3 приводу гриж живота. 


\section{Матеріали і методи дослідження}

Проведено експериментальне дослідження на дорослих самцях білих щурів лінії Wistar, розділених на три групи.

Основна група - тварини, у яких армований металевим каркасом поліпропіленовий імплантат розташовували в передочеревинному шарі передньої черевної стінки і здійснювали годування колагеном у вигляді порошку в дозі 100 мг на 1 кг маси тіла протягом 1,5 місяця. Забір матеріалу здійснювали через 15 (n=10), 30 (n=10) і $90(\mathrm{n}=10)$ діб.

Контрольна група - тварини, у яких армований металевим каркасом поліпропіленовий імплантат розташовували в передочеревинному шарі передньої черевної стінки, по краях швами не фіксували. Забір матеріалу здійснювали через $15(\mathrm{n}=10), 30(\mathrm{n}=10)$ і 90 (n=10) діб.

Порівняльна група - тварини, у яких поліпропіленовий імплантат розташовували в передочеревинному шарі передньої черевної стінки максимально рівно, по краях фіксували швами. Забір матеріалу здійснювали через $15(\mathrm{n}=8), 30(\mathrm{n}=8)$ і $90(\mathrm{n}=8)$ діб.

Застосовували дрібнопористу стерильну поліпропіленову сітку з каркасом 3 нітинолу і без нього. Здійснювали імплантацію сітчастого протеза в передочеревинний шар по зовнішньому краю піхви прямого м'яза. Каркасну сітку не фіксували. Безкаркасну сітку фіксували вузловими швами до м'язів по кутах сітки.
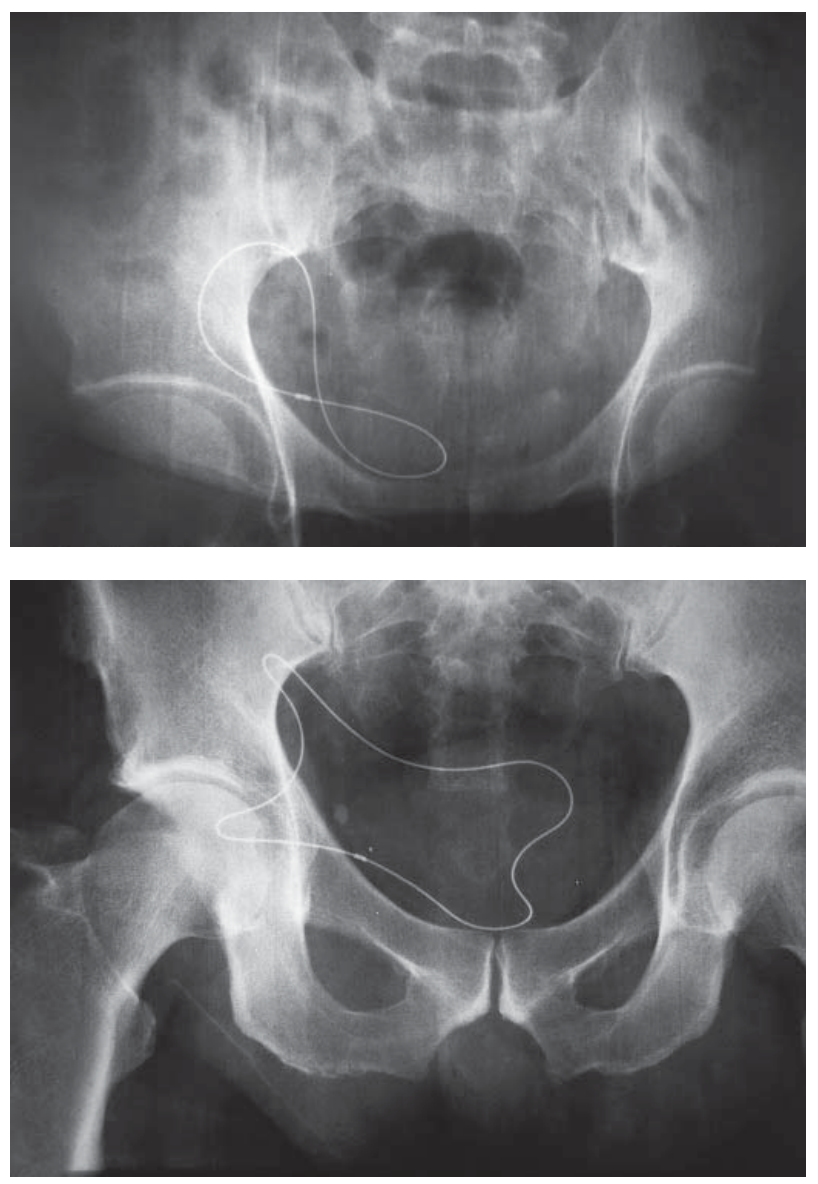

Рентгенограми хворих, оперованих із застосуванням поліпропіленових сіток з нитіноловим каркасом.
Евтаназію виконували на 15, 30 і 90-ту добу шляхом введення летальної дози тіопенталу натрію (30 мг на 100 г маси тіла тварини). Поліпропіленову сітку видаляли разом з навколишніми тканинами (підшкірна клітковина, фасція, м'язова тканина, очеревина) та досліджували. Отриманий матеріал за загальноприйнятими методиками фіксували і фарбували. Зрілість колагенових волокон визначали за методом ван Гізона та Хейла.

Вивчено результати лікування 57 хворих, які були прооперовані з приводу зовнішніх гриж черевної порожнини з використанням каркасних поліпропіленових сітчастих протезів, розташованих sub lay. Серед хворих чоловіків було 36 (71,3\%), жінок - 21 (28,7\%). Середній вік пацієнтів становив $(57 \pm 12,2)$ року. Наймолодшому пацієнтові було 23, найстаршому - 87 років. Найбільше було хворих у віці від 41 до 70 років. Загальний стан хворих, які не мали супутньої патології, був задовільний. Загальний стан середньої тяжкості був у хворих, які мали супутню патологію.

Для проведення порівняльного аналізу хворі були поділені на дві групи: основну - 31 хворий, що отримував після операції препарат колаген (8 грамів щоденно протягом 1,5 місяця), і контрольну - 26 хворих, які не отримували цього препарату.

Пахвинна грижа була у 19 (61,3\%) хворих основної групи і у 9 (34,6\%) хворих контрольної групи, пупкова відповідно у 3 (9,7\%) і 6 (23,14\%), вентральна - у 1 (3,2\%) і 2 (7,7\%), післяопераційна - у 8 (25,84\%) і 9 (34,6\%).

В обох групах хворих виконана алопластика сітчастим поліпропіленовим протезом різних форм і розмірів, по периметру якого фіксований металевий замкнутий гнучкий каркас із сплаву нікелю і титану - нитінолу, якому властиві значна гнучкість і «пам'ять форми», що сприяє постійній розправленості сітки, незмінності iii площі, повному приляганню до щільних шарів черевної стінки. Обов'язковою умовою при встановленні сітчастого поліпропіленового протеза було розташування його в передочеревинному шарі - sub lay.

Розташування і форму сітчастого протеза в післяопераційному періоді контролювали шляхом рентгенографії органів черевної порожнини (див. рисунок). Використовувались протези:

OVL-S (овальна мала сітка) розмірами 7,2 × 8,88 cм,

OVL-M (овальна середня сітка) розмірами 9,37 $\times$ $11,28 \mathrm{~cm}$

SLD-S (мала сітка у формі щита) розмірами 10,31 × $14,94 \mathrm{~cm}$,

SLD-M (середня сітка у формі щита) розмірами 11,58 $\times 16,66 \mathrm{~cm}$,

SLD- L (велика сітка у формі щита) розмірами 13,61 $\times 18,5 \mathrm{~cm}$,

HYB-S (комбінована мала сітка) розмірами 8,81 × $11,28 \mathrm{~cm}$.

Усім хворим проводили стандартну профілактику інфекційних ускладнень.

\section{Результати}

Дослідження гістологічних препаратів через 15 діб довкола сітки як чужорідного об'єкта виявило початкове формування тонкої сполучнотканинної капсули, де серед великої кількості клітин запального інфільтра- 
ту (переважно лімфоцити, плазмоцити з великою домішкою нейтрофільних гранулоцитів, макрофагів й гемосидерофагів та розсіяними молодими фібробластами та лаброцитами) була досить велика кількість новоутворених капілярів. Вживання колагену приводило до збільшення кількості клітин запального інфільтрату за рахунок виразної інфільтрації лімфоцитами та плазмоцитами і значного збільшення кількості макрофагів, що може бути розцінено як один із факторів сприяння росту судин і прояв місцевих імунорегуляторних реакцій. Через три місяці кількість цих клітин у всіх групах була однаковою.

Під час дослідження гістологічних препаратів контрольної та порівняльної груп візуалізовано тонкі колагеновмісні фібрили (в середньому завтовшки 1 - 3 мкм), розташовані невпорядковано як у зоні сітки, так і довкола неї. У разі використання каркасної сітки та колагену виявляли основної речовини дещо більше, було добре розвинуте мікроциркуляторне русло, а новоутворені капіляри мали поперечну орієнтацію до поверхні черевної стінки. Загалом у контрольній та порівняльній групах неоколагеногенез був подібний. Також виразними були набряк міжклітинного матриксу, повнокров'я судин та стази в них.

Через 30 діб виявлені зміни відповідали проліферативній фазі загоєння ран. Встановлено переважання волокнистих елементів матриксу над клітинними. Причому в основній групі кількість еластичних волокон була більша.

Результати наших досліджень свідчать (і це відповідає загальним уявленням про патогенез), що внаслідок появи численних фібробластів у місцях введення сітки виникають поля фіброзу. Встановлено, що у разі вживання препарату колагену поля фіброзу були менші, а новоутворені волокна колагену мали впорядковану структуру, меншу товщину, більшу щільність. Еластичні волокна спостерігали у більшій кількості не лише по периферії сполучної тканини, а й у центральних ділянках та формували виразний сітчастий малюнок.

Імплантація сітки 3 подальшим прийомом колагену приводила вже починаючи з 15-ї доби до значного збільшення (на 19,6\%) середньої кількості судин у зоні експерименту. В подальшому це співвідношення зберігалося. Очевидно, що прийом колагену стимулює неоангіогенез. Середній діаметр артеріол та венул вказував на поступове синхронне збільшення просвіту всіх видів дрібних судин та непрямо свідчив про збільшення кровопостачання довкола сітки.

Після хірургічного лікування зовнішніх гриж живота загальних ускладнень і летальних випадків в основній та контрольній групах не було. Серед ускладнень з боку післяопераційної рани серому спостерігали у 1 (3,2\%) хворого основної групи і у 2 (7,7\%) хворих контрольної групи, запальний інфільтрат, який вилікували консервативно - у 1 (3,8\%) хворого контрольної групи.

Віддалені результати хірургічного лікування і використання препарату колагену вивчались у період від 6 місяців до 2 років. В основній групі рецидив виявлено у 1 (3,2\%) хворого, в контрольній групі - у 2 (7,7\%) хворих. При виконанні УЗ-діагностики за допомогою апарата TOSHIBA NEMIO MX з лінійним датчиком PLM503AT частотою 6 МГц імплантованих сітчастих протезів через 1, 6 і 12 міс після операції вимірювалась товщина комплексу сітчастого протеза із сполучнотканинним компонентом. В основній групі середня товщина комплексу сітчастого протеза із сполучнотканинним шаром через 1 міс становила $(1,0 \pm 0,11)$ мм, у контрольній групі - $(0,8$ $\pm 0,19)$ мм $(\mathrm{p}<0,05)$, через 6 міс - відповідно $(0,9 \pm 0,32)$ і $(0,8 \pm 0,51)$ мм. Через 12 міс товщина комплексу сітчастого протеза із сполучнотканинним шаром в обох групах була приблизно однаковою і коливалася в межах 0,6 0,7 мм, що корелює 3 даними експериментальної роботи з вивчення впливу препарату колагену на формування сполучнотканинних структур у щурів [4].

Частота розвитку гіпертрофічних рубців помітно нижче в основній групі - $2(6,5 \%)$ випадки, ніж у контрольній - 4 (15,4\%) випадки $(\mathrm{p}<0,05)$. Середня тривалість перебування хворих у стаціонарі суттєво не відрізнялась - відповідно 4,4 і 4,1 дня.

Обговорення. Імплантація поліпроленової сітки викликає транзиторну запальну реакцію, виражену в незначній мірі, з подальшим утворенням тонкого шару сполучної тканини, яка проростає крізь сітку, поєднуючи таким чином сітку з оточуючими тканинами. Сітка зберігає свою еластичність і м'якість і не заважає процесам нормального загоєння рани. Матеріал не розсмоктується і не руйнується.

\section{Висновки}

1. Застосування колагену стимулюе неоангіогенез, $€$ профілактикою ішемізації тканин у зоні алотрансплантату за рахунок збільшення кровоносного русла та зберігає функціонуючою значну частину новоутворених судин.

2. Колаген оптимізує утворення достатньої кількості зрілої сполучної тканини у периімплантаційній зоні без погіршення механічних властивостей алопротеза.

3. Використання препарату колагену позитивно впливає на товщину сполучнотканинного компонента в зоні поліпропіленового протеза в ранньому післяопераційному періоді.

\section{References}

1. Gonzalez R, Fugate K, McClusky D III, et al. Relationship between tissue ingrowth and mesh contraction. World J Surg. 2005;29:1038-43.

2. Hostevskoy AA. Obosnovanie i otsenka effektivnosti novykh materialov i metodov $\mathrm{v}$ lecheniy posleoperatsyonnykh ventralnikh hryzh (klynykoeksperymentalnoe issledovanie). [thesis]. SPb; 2008. 16 s. [In Russian].

3. Chetverykov SH, Rosha LH, Atanasov DV, Mikhailov OS. Mistseve vykorystannia ta rol klitynnykh faktoriv rostu i tkanynnoy integratsii kompozytnoho dvokomponentnoho sitchastoho implantata (eksperymentalna model). In: Materialy IX naukovo-praktychnoi konferentsii «Suchasni sposoby ta tekhnolohii u khirurhichnomu likuvanni hryzh zhyvota»; 2016. 71-3[In Ukrainian].

4. Zaporozhchenko BS, Kholodov IH, Kolodiy VV, Bondarets DA, Rosha LH. Eksperymentalne doslidzhennia vplyvu preparatu kolahen na formuvannia spoluchnotkanynnykh struktur $\mathrm{v}$ zoni implantatsii sitchastoho proteza. Ukrainskyi zhurnal khirurhii. 2017;1(32):12-8. [In Ukrainian]. 